\title{
PENGARUH KEPEMIMPINAN MUTU DAN KEWIRAUSAHAAN KEPALA SEKOLAH TERHADAP KETERCAPAIAN SNP DI SMKN 1 PURWOREJO
}

\author{
Faya Izma Alayda ${ }^{1}$ dan Indah Wahyuni ${ }^{2}$ \\ ${ }^{1,2}$ Pendidikan Teknik Sipil dan Perencanaan, FT, UNY \\ Email: fayaizma.2017@student.uny.ac.id
}

\begin{abstract}
ABSTRAK
Tujuan penelitian mengetahui tingkat ketercapaian 1) kepemimpinan mutu, 2) kepemimpinan kewirausahaan, dan 3) SNP; mengetahui besarnya pengaruh 4) kepemimpinan mutu terhadap SNP, 5) kepemimpinan kewirausahaan terhadap SNP, 6) kepemimpinan mutu dan kewirausahaan secara bersama-sama terhadap SNP; dan 7) mengetahui hubungan kepemimpinan mutu dengan kewirausahaan. Merupakan penelitian prediksi korelasi dengan pendekatan kuantitatif deskriptif. Subjek penelitiannya 130 orang tenaga pendidik dan kependidikan dengan sampel 30 orang. Menggunakan instrumen angket tertutup melalui google form menggunakan skala likert 1 sampai 4. Teknik analisis data menggunakan analisis deskriptif dan regresi. Hasil penelitian menunjukkan tingkat ketercapaian 1) kepemimpinan mutu dengan kategori sangat baik $(67,742 \%), 2)$ kepemimpinan kewirausahaan dengan kategori baik (61,3\%), 3) ketercapaian SNP dengan kategori sangat tinggi $(90,32 \%), 4)$ kepemimpinan mutu berpengaruh positif terhadap SNP $(26,8 \%)$, 5) kepemimpinan kewirausahaan berpengaruh positif terhadap SNP $(35,3 \%), 6)$ kepemimpinan mutu dan kewirausahaan secara bersama-sama berpengaruh positif terhadap SNP $(56,4 \%), 7)$ tidak terdapat hubungan kepemimpinan mutu dan kewirausahaan.
\end{abstract}

Kata kunci: Kepemimpinan, Mutu, Kewirausahaan, Kepala Sekolah, dan Pendidikan

\section{ABSTRACT}

The purpose of this study are to determine the level of achievement of 1) quality leadership, 2) entrepreneurial leadership, and 3) SNP; knowing the magnitude of the influence of 4) quality leadership on the $S N P, 5)$ entrepreneurial leadership on the SNP, 6) quality leadership and entrepreneurship together on the SNP; and 7) knowing the relationship between quality leadership and entrepreneurship. It is a correlation prediction research with a descriptive quantitative approach. The research subjects were 130 educators and education team with a sample of 30 people. Using a closed questionnaire instrument through google form using a Likert scale of 1 up to 4. The data analysis technique used descriptive analysis and regression. The results showed the level of achievement of 1) quality leadership in the very good category $(67.742 \%)$, 2) entrepreneurial leadership in the good category (61.3\%), 3) the level of achievement of SNP in the very high category (90.32\%), 4) leadership quality has a positive effect on SNP (26.8\%), 5) entrepreneurial leadership has a positive effect on SNP (35.3\%), 6) quality leadership and entrepreneurship together have a positive effect on $\operatorname{SNP}(56.4 \%)$, 7) there is no relationship between quality leadership and entrepreneurship.

Keywords: Leadership, Quality, Entrepreneurship, Principal, and Education

\section{PENDAHULUAN}

Permasalahan pada kepemimpinan seringkali menimbulkan perhatian yang menarik karena organisasi bisa dikatakan berhasil ataupun gagal dapat disebabkan oleh mutu kepemimpinannya. Kepemimpinan merupakan posisi kunci dalam aspek manajerial dalam kehidupan organisasi. Banyak temuan dan opini penelitian diusulkan oleh para peneliti sebelumnya menunjukkan bahwa terdapat hubungan peningkatan mutu pendidikan dengan kepemimpinan kepala sekolah. Menurut pendapat Gordon (2007), tanggung jawab utama pengelola sekolah adalah seorang pemimpin. Sehingga, para ahli sepakat bahwa kepemimpinan dapat meningkatkan kinerja suatu organisasi. Hal ini sejalan dengan penelitian yang dilakukan 
oleh Sri (2014) dan Niken (2018) yang mengungkap bahwa kepemimpinan kepala sekolah dapat mempengaruhi kinerja guru. Sehubungan dengan hal tersebut, terdapat berberapa kompetensi yang wajib dimiliki kepala sekolah yang tercantum dalam Peraturan Menteri Pendidikan Nasional Nomor 13 Tahun 2007, terdapat lima kompetensi dasar yang harus dimiliki kepala sekolah, antara lain; 1) kompetensi kepribadian, 2) kompetensi manajerial, 3) kompetensi kewirausahaan, 4) kompetensi supervisi, dan 5) kompetensi sosial.

Peran penting kepala sekolah adalah kepala sekolah wajib menyusun program dan rencana sekolah yang berkualitas, menjalankan rencana tersebut secara konsisten dan melakukan supervisi yang baik. Dalam menjalankan fungsi kepemimpinan, kepala sekolah diharapkan senantiasa melaksanakan kepemimpinan mutu. Tujuan kepemimpinan mutu adalah memiliki visi dan misi yang proaktif, memberikan inspirasi, menunjukkan konsistensi yang bermutu, sangat terbuka dalam komunikasi, mengembangkan semangat tim, memahami kebutuhan dan harapan warga sekolah. Dalam pencapaian kepemimpinan mutu, menurut Sallis dalam Husaini (2016), pemimipin yang bermutu harus memiliki sifat-sifat sebagai berikut.

1) Memiliki visi untuk kualitas organisasi.

2) Memiliki komitmen yang kuat terhadap kualitas.

3) Secara efektif menyampaikan informasi yang berkualitas.

4) Memastikan bahwa kebutuhan pelanggan menjadi fokus strategi dan menerapkan strategi tersebut sebanyak mungkin.

5) Pandu pengembangan staf.

6) Ketika ada masalah tanpa bukti yang meyakinkan, mohon jangan menyalahkan pihak lain, karena kebanyakan masalah disebabkan oleh hasil kebijakan kelembagaan, bukan karena kesalahan personel.

7) Inovasi kelembagaan terdepan.

8) Mampu memastikan bahwa struktur organisasi memiliki uraian tugas yang jelas untuk setiap karyawan.

9) Berkomitmen untuk mengurangi atau bahkan menghilangkan hambatan pribadi, organisasi dan budaya.

10) Membentuk tim kerja yang efektif.

11) Menetapkan mekanisme yang tepat untukmemantau dan mengevaluasi keberhasilan pencapaian kualitas.

Terselenggaranya pendidikan di sekolah dipengaruhi oleh kinerja kepala sekolah yang harus mampu memimpin serta mengarahkan personilnya sebagai alat untuk menggali sumberdaya yang dimiliki sekolah. Dalam hal ini kepemimpinan kewirausahaan yang baik dirasa diperlukan sebagai penjamin kualitas sekolah agar sesuai tujuan pendidikan di Indonesia. Kepemimpinan kewirausahaan adalah seorangpemimpin yang mampu mengembangkan potensi sekolah sesuai dengan SDM yang dimilikinya. Sesuai dengan Pasal 13 Peraturan Menteri Pendidikan Tahun 2007 tentang Standar Kepala Sekolah, ciri-ciri kemampuan kewirausahaan yang harus dimiliki kepala sekolah adalah sebagai berikut.

1) Menciptakan inovasi yang berguna untuk perkembangan sekolah/madrasah.

2) Berusaha keras menjadikan sekolah/madrasah sebagai organisasi pembelajaran yang efektif dan mencapai kesuksesan.

3) Memiliki motivasi yang kuat untukberhasil menjalankan tugas pokok 
dan fungsinya sebagai pemimpin sekolah/madrasah.

4) Pantang menyerah, dan selalu mencari solusi terbaik untuk menghadapi kendala yang dihadapi sekolah/madrasah.

5) Memiliki naluri kewirausahaan dalam mengelola kegiatan sekolah/madrasah sebagai sumber belajar bagi peserta didik.

Hasil penelitian Suhartatik (2012) menunjukkan bahwa dari perspektif kinerja akademik siswa dan peningkatan kualitas manajemen sekolah, kepemimpinan wirausaha dapat meningkatkan produktivitas sekolah, karena komunikasi dan kerjasama di lingkungan sekolah adalah untuk melaksanakan tugas untuk memberikan kualitas. Kepemimpinan kewirausahaan menjadi salah satu model terdepan yang dapat memprediksi era yang berubah seiring perkembangan dan globalisasi.

Untuk mencapai tujuan dan mutu pendidikan diperlukan berberapa strategi dalam mencapainya. Banyak usaha yang telah diupayakan pemerintah guna meningkatkan mutu pendidikan di Indonesia, seperti menerbitkan Peraturan Pemerintah Nomor 13 Tahun 2015 tentang Standar Nasional Pendidikan. Ruang lingkup standar nasional pendidikan yang harus dilaksanakan oleh penyelenggara sekolah, yang terdiri dari delapan standar. Delapan standar yang terdaftar ialah: (1) standar isi, (2) standar proses, (3) standar kompetensi lulusan, (4) standar pendidik dan tenaga kependidikan, (5) standar sarana dan prasarana, (6) standar pengelolaan, (7) standar pembiayaan, dan (8) standar penilaian pendidikan. Kedelapan standarpendidikan tersebut wajib dicapai dalam penyelenggaraan pendidikan pada setiap jenjang pendidikan walaupun dalam pelaksanaannya masih terdapat banyak masalah pendidikan yang dihadapi.

Berdasarkan penjelasan diatas ketercapaian SNP dapat dipengaruhi oleh kinerja kepemimpinan yang dimiliki kepala sekolah yang dalam penelitian ini akan fokus pada kepemimpinan mutu dan kepemimpinan kewirausahaan. Kinerja sekolah sangat bergantung pada mutu kepala sekolah sebagai seorang pemimpin pendidikan, dan salah satu faktor yang mempengaruhi dalam meningkatkan mutu pendidikan adalah kepemimpinan kepala sekolah (Restu, 2017). Kepemimpinan mutu dianggap penting dan tidak bisa diabaikan sebagai sarana peningkatan mutu. Sedangkan dalam peningkatan kinerja kepala sekolah, diperlukan kepemimpinan kewirausahaan sebagai sarana pengembangan potensi sekolah sesuai dengan sumber daya yang dimiliki sekolah.

\section{METODE}

Penelitian ini merupakan penelitian perediksi dan korelasi dengan pendekatan kuantitafif deskriptif, dengan menggunakan desain ex post facto. Penelitian ini dilaksanakan pada 31 Agustus - 30 September 2020 di SMKN 1 Purworejo yang beralamat di Jalan Tentara Pelajar RT 03/07 Kledung Kradenan, Kecamatan Banyu Urip, Kabupaten Purworejo, Jawa Tengah. Sampel yang diteliti adalah 30 tenaga pendidik dan kependidikan di SMKN 1 Purworejo. Penelitian ini mencakup tiga variabel. Adapun yang menjadi variabel bebas adalah kepemimpinan mutu (diberi simbol X1), kepemimpinan kewirausahaan (diberi simbol X2) dan variabel terikatnya adalah Standar Nasional Pendidikan (diberi simbol Y).Teknik pengumpulan data yang digunakan adalah kuisioner angket yaitu 
seperangkat pernyataan yang dibuat oleh peneliti dalam bentuk google form. Dalam penelitian ini menggunakan angket tertutup yang berisi butir pertanyaan yang telah disediakan beserta pilihan jawaban, sehingga responden penelitian hanya memilih jawaban pernyataan yang telah disediakan oleh peneliti tanpa harus menguraikankan dengan lebih rinci.

Teknik analisis yang digunakan pada penelitian ini yaitu:

1. Analisis Deskriptif Variabel

Analisis deskriptif ini digunakan untuk mendapatkan gambaran penyebaran data hasil penelitian pada masing-masing variabel berdasarkan kategori. Skala yang digunakan adalah skala likert dengan rentang 1 sampai dengan 4 .

Tabel 1. Norma Batas Pengkategorian Nilai Skor 100

\begin{tabular}{|c|c|c|c|}
\hline No & Interval & $\begin{array}{l}\text { Skala } \\
\text { Skor }\end{array}$ & Kategori \\
\hline 1 & $\geq(\mathrm{Mi}+1.5 \mathrm{SDi})$ & $\begin{array}{ll}\mathrm{X} & > \\
81,25 & \end{array}$ & Sangat Baik \\
\hline 2 & $\begin{array}{l}\mathrm{Mi} \mathrm{s} / \mathrm{d}(\mathrm{Mi}+1.5 \\
\mathrm{SDi})\end{array}$ & $\begin{array}{l}62,5<X \\
\leq 81,25\end{array}$ & Baik \\
\hline 3 & $(\mathrm{Mi}-1.5 \mathrm{SDi})$ & $\begin{array}{l}43,75< \\
X \leq 62,5\end{array}$ & Tidak Baik \\
\hline 4 & $\leq(\mathrm{Mi}-1.5 \mathrm{SDi})$ & $\begin{array}{l}X \\
43,75\end{array}$ & $\begin{array}{l}\text { Sangat } \\
\text { Tidak Baik }\end{array}$ \\
\hline
\end{tabular}

\section{Uji Prasyarat Analisis}

Pada uji prasyarat analisis menggunakan uji multikolinearitas, uji normalitas, uji linieritas dan uji homogenitas.

\section{Uji Hipotesis}

Uji hipotesis menggunakan analisis regresi sederhana dan analisis regresi berganda.

\section{HASIL DAN PEMBAHASAN}

Variabel kepemimpinan mutu (X1) diperoleh mean sebesar 171,74, median 177 dengan standar deviasi sebesar 16,815. Variabel kepemimpinan kewirausahaan (X2) kepala sekolah diperoleh mean sebesar
92,65, median sebesar 93, dan standar deviasi sebesar 9,718. Variabel Standar Nasional Pendidikan (Y) diperoleh mean sebesar 484,1, median sebesar 494, dan standar deviasi sebesar 37,484. Secara rinci dengan distribusi frekuensi deskripsi masing-masing variabel dijelaskan sebagai berikut.

1. Kepemimpinan Mutu Kepala Sekolah (X1)

Data variabel kepemimpinan mutu kepala sekolah di SMKN 1 Purworejo diperoleh melalui kuisioner yang terdiri dari 50 butir pernyataan dengan jumlah responden 30 orang tenaga pendidik dan tenaga kependidikan dari SMK $\mathrm{N} \quad 1$ Purworejo. Ada empat alternatif jawaban denggan skor tertinggiq4 poin dan skor terendah 1 poin. Berdasarkan hasil analisa deskriptif yang diolah dengan menggunakan bantuan aplikasi SPSS versi 22.0 for windows, pada variabel kepemimpinan mutu kepala sekolah (X1) dapat diketahui rerata (mean) sebesar 171,74, median (Me) sebesar 177, dan standar deviasi sebesar 16,815. Berdasarkan angket kualitas kepemimpinan yang disebarkan juga terlihat bahwa nilai tertinggi variabel kepemimpinan mutu kepala sekolah adalah 197 poin dan nilai terendah 140 poin. Berikut ini adalah tabel distribusi frekuensi variabel kualitas kepemimpinan kepala sekolah.

Berdasarkan Tabel 2, didapat frekuensi paling banyak pada data dengan interval kelas 180-189 sedangkan frekuensi paling sedikit terdapat pada data dengan interval kelas 160-169. Rerata skor data kepemimpinan mutu kepala sekolah adalah 171,74 yang terletak pada data dengan interval 170-179. 
Tabel 2. Distribusi Frekuensi Variabel Kepemimpinan Mutu Kepala Sekolah $\left(\mathrm{X}_{1}\right)$

\begin{tabular}{ccc}
\hline No & Interval Kelas & Frekuensi \\
\hline 1 & $140-149$ & 3 \\
2 & $150-159$ & 7 \\
3 & $160-169$ & 2 \\
4 & $170-179$ & 6 \\
5 & $180-189$ & 8 \\
6 & $190-200$ & 5 \\
& Jumlah & 30 \\
\hline
\end{tabular}

Penentuan kecenderungan variabel kepemimpian mutu kepala sekolah terhadap ketercapaian Standar Nasional Pendidikan, dikelompokkan menjadi empat kategori sebagai berikut.

Tabel 3. Kecenderungan Frekuensi Kepemimpinan Mutu Kepala Sekolah $\left(\mathrm{X}_{1}\right)$

\begin{tabular}{|c|c|c|c|c|}
\hline No & Rentang & Ket & $\mathbf{n}$ & $\%$ \\
\hline 1 & $X>162,5$ & $\begin{array}{l}\text { Sangat } \\
\text { Baik }\end{array}$ & 20 & 67,7 \\
\hline 2 & $125<X \leq 162,5$ & Baik & 10 & 32,3 \\
\hline 3 & $87,5<X \leq 125$ & $\begin{array}{l}\text { Tidak } \\
\text { Baik } \\
\text { Sangat }\end{array}$ & 0 & 0 \\
\hline \multirow[t]{2}{*}{4} & $X \leq 87,5$ & $\begin{array}{l}\text { Tidak } \\
\text { Baik }\end{array}$ & 0 & 0 \\
\hline & Jumlah & & 30 & 100 \\
\hline
\end{tabular}

Pada variabel kepemimpinan mutu terdapat lima variabel dengan perolehan presentase ketercapaian sebagai berikut: (1) visi yang jelas memperoleh presentase sebesar $88,4 \%$ yang dikategorikan sangat sesuai, (2) kerja keras memperoleh prosentase sebesar $82,9 \%$ yang dikategorikan sangat sesuai, (3) ketekunan yang penuh ketabahan memperoleh prosentase sebesar $85,6 \%$, (4) pelayanan dengan rendah hati memperoleh prosntase sebesar 83,8\%, (5) disiplin yang kuat memperoleh prosentase sebesar $88,7 \%$. Hasil persentase dari masing-masing indikator tersebut apabila disajikan dengan diagram batang akan tampak sebagai berikut.

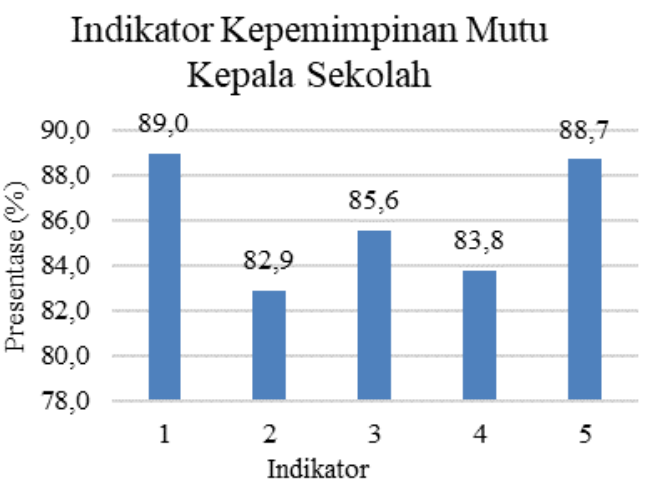

Gambar 1. Diagram Batang Indikator Kepemimpinan Mutu Kepala Sekolah

Tingkat ketercapaian kepemimpinan mutu (X1) kepala sekolah. Berdasarkan Tabel 3, diketahui bahwa kepemimpinan mutu kepala sekolah di SMKN 1 Purworejo pada kategori sangat baik sebesar $67,742 \%$ dan pada kategori baik sebesar 32,258\%. Hal ini dapat dikatakan bahwa tingkat kepemimpinan mutu di SMKN 1 Purworejo berada pada kategori sangat baik.

2. Kepemimpinan Kewirausahaan Kepala Sekolah (X2)

Data variabel kepemimpinan kewirausahaan kepala sekolah di SMKN 1 Purworejo diperoleh melalui angket yang terdiri dari 30 item pernyataan dengan jumlah responden 30 tenaga pendidik dan kependidikan di SMKN 1 Purworejo. Ada empat alternatif jawaban dengan skor tertinggi 4 dan skor terendah 1 . Berdasarkan hasil analisa deskriptif yang diolah dengan menggunakan bantuan aplikasi SPSS versi 22.0 for windows, untuk variabel kepemimpinan kewirausahaan kepala sekolah (X2) dapat diketahui rerata (mean) sebesar 92,65, median (Me) sebesar 93, dan standar deviasi sebesar 9,716. Berdasarkan angket kepemimpinan kewirausahaan kepala sekolah yang disebar dapat diketahui pula skor maksimal untuk variabel 
kepemimpinan kewirausahaan kepala sekolah yaitu 108 dan skor minimal yaitu 76 . Berikut tabel distribusi frekuensi untuk variabel kepemimpinan kewirausahaan kepala sekolah.

Tabel 4. Distribusi Frekuensi Variabel kepemimpinan Kewirausahaan Kepala Sekolah $\left(\mathrm{X}_{2}\right)$

\begin{tabular}{ccc}
\hline No & Interval Kelas & Frekuensi \\
\hline 1 & $75-80$ & 4 \\
2 & $81-86$ & 7 \\
3 & $87-92$ & 3 \\
4 & $93-98$ & 6 \\
5 & $99-104$ & 8 \\
6 & $105-110$ & 3 \\
& Jumlah & 30 \\
\hline
\end{tabular}

Berdasarkan Tabel 4, didapatkan frekuensi paling banyak pada data dengan interval kelas 99-104 sedangkan frekuensi paling sedikit terdapat pada data dengan interval kelas 87-92 dan 105-110. Rata-rata skor data kepemimpinan kewirausahaan kepala sekolah adalah 92,65 yang terletak pada data dengan interval antara 87-92 dan 93-98.

Penentuan kecenderungan variabel kepemimpian kewirausahaan kepala sekolah terhadap ketercapaian Standar Nasional Pendidikan, dikelompokkan menjadi empat kategori sebagai berikut.

Tabel 5. Kecenderungan Frekuensi Kepemimpinan KWU Kepala Sekolah $\left(\mathrm{X}_{2}\right)$

\begin{tabular}{|c|c|c|c|c|}
\hline No & Rentang & Ket & $\mathbf{n}$ & $\%$ \\
\hline 1 & $X>97.5$ & Sangat Baik & 12 & 38,7 \\
\hline 2 & $75<X \leq 97,5$ & Baik & 18 & 61,3 \\
\hline 3 & $52,5<X \leq 75$ & Tidak Baik & 0 & 0 \\
\hline 4 & $X \leq 52,5$ & Sangat Tidak Baik & 0 & 0 \\
\hline \multicolumn{3}{|c|}{ Jumlah } & 30 & 100 \\
\hline
\end{tabular}

Berdasarkan Tabel 5, diketahui bahwa kepemimpinan kewirausahaan kepala sekolah di SMKN 1 Purworejo pada kategori sangat baik sebesar 38,7\% dan pada kategori baik sebesar $61,3 \%$. Hal ini dapat dikatakan bahwa tingkat ketercapaian kepemimpinan kewirausahaan kepala sekolah di SMKN 1 Purworejo berada pada kategori baik.

3. Standar Nasional Pendidikan (Y)

Data variabel Standar Nasional Pendidikan di SMK N 1 Purworejo diperoleh melalui angket yang terdiri dari 133 butir pernyataan dengan jumlah responden 30 orang. Ada 4 alternatif jawaban dengan skor tertinggi 4 dan skor terendah 1. Berdasarkan hasil analisa deskriptif yang diolah dengan menggunakan bantuan aplikasi SPSS versi 22.0 for windows, untuk variabel Standar Nasional Pendidikan (Y) dapat diketahui rerata (mean) sebesar 484,1, median (Me) sebesar 494, dan standar deviasi sebesar 37,484. Berdasarkan angket Standar Nasional Pendidikan yang disebar dapat diketahui pula skor maksimal untuk variabel SNP yaitu 531 dan skor minimal yaitu 390. Berikut tabel distribusi frekuensi untuk variabel Standar Nasional Pendidikan.

\begin{tabular}{ccc}
\multicolumn{3}{c}{ Tabel 6. Distribusi Frekuensi dari Variabel SNP (Y) } \\
\hline No & Interval Kelas & Frekuensi \\
\hline 1 & $390-413$ & 3 \\
2 & $414-437$ & 5 \\
3 & $438-461$ & 5 \\
4 & $462-485$ & 12 \\
5 & $486-509$ & 19 \\
6 & $510-533$ & 26 \\
& Jumlah & 30 \\
\hline
\end{tabular}

Berdasarkan Tabel 6, didapat frekuensi paling banyak pada data dengan interval kelas 510-533 sedangkan frekuensi paling sedikit terdapat pada data dengan interval kelas 390-413. Rerata skor data SNP adalah 484,10 yang terletak pada data dengan interval 462-485.

Penentuan kecenderungan variabel SNP, dikelompokkan menjadi empat 
kategori sama dengan perhitungan pada variabel sebelumnya. Tabel kategori kecenderungan frekuensi untuk variabel SNP (Y) adalah sebagai berikut.

Tabel 7. Kecenderungan Frekuensi dari Variabel SNP (Y)

\begin{tabular}{ccccc}
\hline No & Rentang & Ket & n & \% \\
\hline 1 & $\mathrm{X}>432,25$ & $\begin{array}{l}\text { Sangat } \\
\text { Tinggi }\end{array}$ & 27 & 90,32 \\
2 & $\begin{array}{l}332,5<\mathrm{X} \leq \\
432,25\end{array}$ & $\begin{array}{l}\text { Tinggi } \\
3\end{array}$ & 3 & 9,68 \\
3 & $\begin{array}{l}232,75<\mathrm{X} \leq \\
432,5\end{array}$ & $\begin{array}{l}\text { Rendah } \\
4\end{array}$ & 0 & 0 \\
& $\mathrm{X} \leq 232,75$ & Sangat & 0 & 0 \\
& Jumlah & & 30 & 100 \\
\hline
\end{tabular}

Berdasarkan Tabel 7, diketahui bahwa ketercapaian Standar Nasional Pendidikan di SMKN 1 Purworejo pada kategori sangat tinggi sebesar 90,32\% dan pada kategori tinggi sebesar 9,68\%. Hal ini dapat dikatakan bahwa tingkat ketercapaian Standar Nasional Pendidikan di SMKN 1 Purworejo berada pada kategori sangat tinggi.

Pada variabel Standar Nasional Pendidikan memiliki delapan indikator dengan perolehan presentase ketercapaian pada masing-masing standar untuk 1) standar isi memperoleh presentase sebesar 90,59\% yang dikategorikan sangat sesuai, 2) standar proses memperoleh prosentase sebesar $87 \%$ yang dikategorikan sangat sesuai, 3) standar kompetensi lulusan memperoleh prosentase sebesar 91,2\%, 4) standar pendidik dan tenaga kependidikan memperoleh presentase sebesar 89,4\%, 5) standar sarana dan prasarana memperoleh prosentase sebesar 92,74\%, 6) standar pengelolaan memperoleh prosentase sebesar $95 \%, 7)$ standar pembiayaan memperoleh prosentase sebesar 91,48\%, dan 8) standar penilaian memperoleh prosentase sebesar
91,13\%.Hasil persentase dari masingmasing indikator tersebut apabila disajikan dengan diagram batang akan tampak sebagai berikut.

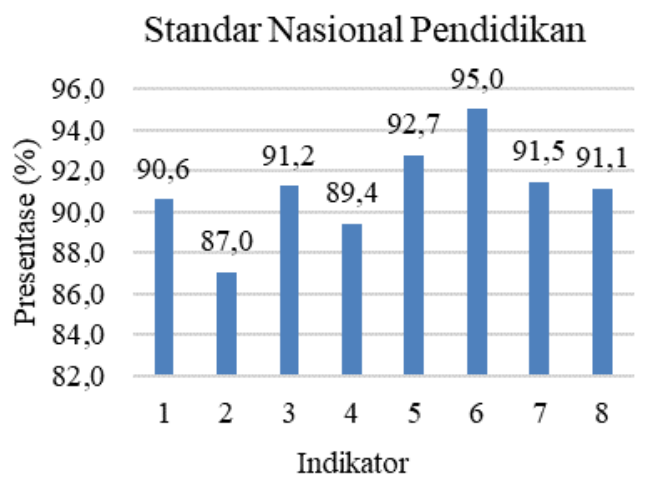

Gambar 2. Diagram Batang Indikator Ketercapaian Standar Nasional Pendidikan

Uji normalitas dilakukan untuk menguji apakah nilai residual berdistribusi normal atau tidak. Nilai residual dikatakan normal jika nilai signifikansinya lebih besar dari 0,05 dan data dikatakan tidak normal jika nilai signifikansinya lebih kecil dari 0,05. Diperoleh nilai Asymp. Sig. (signifikansi) $0,200=20,0 \%$ dan lebih besar dari $5 \%$ atau $(20,0 \%>5 \%)$ atau dapat diartikan (2-tailed) $\geq \alpha(0,200 \geq 0,05)$ berarti data standardized residual maka hipotesis nol diterima dan dengan demikian variabel dependen berdistribusi normal, dan persamaan regresi sudah memenuhi asumsi/prasyarat berdistribusi normal. Hasil uji persyaratan ini memenuhi untuk menganalisis dengan analisis regresi sebagai suatu persyaratannya. Selanjutnya berdasarkan grafik P-Plot, data menyebar sekitar garis diagonal dan mengikuti arah garis diagonal, sehingga model regresi memenuhi asumsi normalitas. Adapun secara lengkap dan rinci dapat diqlihat pada Gambar 9. berikut. 


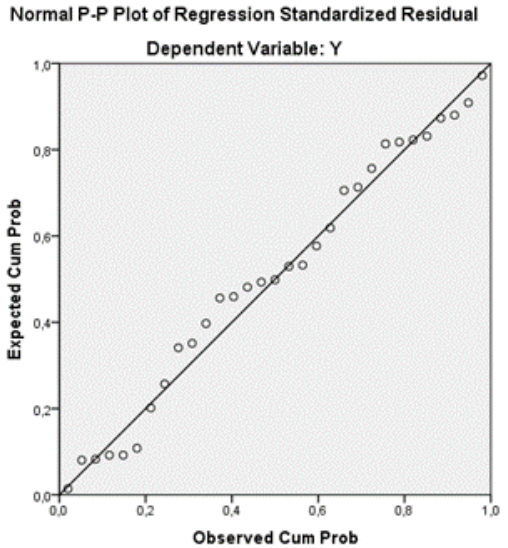

Gambar 3. P-Plot Hasil Uji Normalitas

Dalam Gambar 3, titik-titik mendekati garis lurus berarti data standardized residual berdistribusi normal, maka persamaan regresi sudah memenuhi asumsi/prasyarat berdistribusi normal.

Uji linieritas dilakukan untuk mengetahui hubungan linier antara variabel bebas dengan variabel terikat. Dalam pengujian ini berfungsi untuk mengetahui hubungan linier antara kepemimpinan mutu (X1) dengan Standar Nasional Pendidikan (Y), serta hubungan linier antara kepemimpinan kewirausahan (X2) dengan Standar Nasional Pendidikan (Y). Linieritas antar variabel dapat diketahui dengan uji F. Uji F mempunyai kriteria jika nilai Fhitung lebih kecil atau sama dengan Ftabel pada tingkat signifikansi 5\% maka hubungan antar variabel dikatakan linier. Selain dengan melihat dari nilai $\mathrm{F}$, dapat dilihat juga dari nilai signifikansi, jika nilai signifikansi $<\alpha(5 \%)$ maka dikatan linier, jika nilai signifikansi $>\alpha(5 \%)$ berarti tidak linier.

Tabel 8. Hasil Uji Linieritas Data Penelitian

\begin{tabular}{ccccc}
\hline No & Variabel & Sig. & Acuan & Ket \\
\hline 1 & $\mathrm{X} 1 * \mathrm{Y}$ & 0,334 & 0,05 & Linier \\
2 & $\mathrm{X} 2 * \mathrm{Y}$ & 0,069 & 0,05 & Linier \\
\hline
\end{tabular}

Uji multikolinearitas berfungsi untuk mengetahui adanya korelasi atau hubungan kuat antar variabel bebas dalam sebuah model regresi berganda. Dalam penelitian ini, uji multikolinearitas menggunakan SPSS V.22.0. Untuk mengetahui multikolinearitas, bila nilai tolerance suatu variabel $<0,1$ dan VIF $>10$ makaqdapat diindikasikan variabel tersebut memiliki gejala multikolinieritas.

Tabel 9. Hasil Uji Multikolinieritas

\begin{tabular}{ccccl}
\hline No & Variabel & $\begin{array}{c}\text { Tolera } \\
\text { nce }\end{array}$ & VIF & \multicolumn{1}{c}{ Ket } \\
\hline & & & & $\begin{array}{l}\text { Tidak ada } \\
\text { gejala } \\
\text { multikoline } \\
\text { aritas } \\
\text { Tidak ada } \\
\text { gejala } \\
\text { multikoline } \\
\text { aritas }\end{array}$ \\
\hline
\end{tabular}

Multikolinearitas dapat dilihat dari nilai toleransi yang merupakan kebalikan dari VIF. VIF dengan toleransi memiliki hubungan proporsional terbalik, jika nilai toleransi rendah sama dengan nilai VIF tinggi, begitu pula sebaliknya jika nilai toleransi tinggi maka nilai VIF semakin rendah karena VIF $=1 /$ toleransi. Prinsip pedoman model regresi tanpa multikolinearitas adalah bahwa nilai VIFnya $<10$ dan toleransi $<10 \%(0,1)$. Seperti dapat dilihat dari tabel diqatas, VIF $<10$, toleransi> 0,1 yang berarti tidak terjadi multikolinieritas dalam analisis regresi. Oleh karena itu, pengujian hipotesis memenuhi persyaratan untuk dilanjutkan.

\section{SIMPULAN}

Berdasarkan hasil analisis data yang telah dilakukan, dapat disimpulkan bahwa:

1. Besarnya tingkat ketercapaian kepemimpinan mutu kepala sekolah di SMKN 1 Purworejo masuk kedalam 
Pengaruh Kepemimpinan... (Faya/ hal. 28-37)

kategori sangat baik dengan persentase $67,742 \%$.

2. Besarnya tingkat ketercapaian kepemimpinan kewirausahaan kepala sekolah di SMKN 1 Purworejo masuk kedalam kategori baik dengan persentase $61,3 \%$.

3. Besarnya tingkat ketercapaian SNP di SMKN 1 Purworejo masuk kedalam kategori sangat tinggi dengan persentase $90,32 \%$.

4. Terdapat pengaruh positif dan signifikan antara kepemimpinan mutu kepala sekolah terhadap ketercapaian SNP di SMKN 1 Purworejo sebesar $26,8 \%$.

5. Terdapat pengaruh positif dan signifikan antara kepemimpinan kewirausahaan kepala sekolah terhadap ketercapaian SNP di SMKN 1 Purworejo sebesar 35,3\%.

6. Terdapat pengaruh positif dan signifikan antara kepemimpinan mutu dan kewirausahaan kepala sekolah secara bersama-sama terhadap ketercapaian SNP di SMKN 1 Purworejo sebesar 56,4\%.

7. Tidak terdapat hubungan antara kepemimpinan mutu dan kewirausahaan kepala sekolah di SMKN 1 Purworejo, hal ini ditunjukkan oleh besarnya Sig < $\alpha(0,000<0,589)$.

\section{DAFTAR RUJUKAN}

Departemen Pendidikan Nasional. 2007.

$\begin{array}{lrr}\text { Peraturan } & \text { Menteri } & \text { Pendidikan } \\ \text { Nasional Nomor 13 } & \text { Tahun 2007 } \\ \text { tentang } & \text { Standar } & \text { Kepala } \\ \text { Sekolah/Madrasah. } & \text { Jakarta: } \\ \text { Depdiknas. } & & \end{array}$

Peraturan Menteri Pendidikan tentang Standar Kepala Sekolah/Madrasah. Jakarta: Depdiknas.
Departemen Pendidikan Nasional. 2015. Peraturan Pemerintah Nomor 13 Tahun 2015 tentang Standar Nasional Pendidikan. Jakarta: Depdiknas.

Gordon, Richard. (2007). School leadership and administration. Mc Graw Hill.

Husaini Usman. 2016. Manajemen: teori, praktik dan riset pendidikan. Jakarta: Bumi Aksara.

Niken Akmala Rini. 2018. Jurnal Pendidikan Administrasi Perkantoran: Pengaruh kepemimpinan kepala sekolah dan motivasi kerja terhdapap kinerja guru di SMK Muhammadiyah 2 Bantul. Vol. 7, No. 4. Universitas Negeri Yogyakarta.

Restu Astuti. 2017. Jurnal Administrasi Pendidikan: Strategi dalam meningkatkan mutu pendidikan di sekolah menengah kejuruan sekecamatan Sedayu kabupaten Bantul. Vol 6, No 7. Universitas Negeri Yogyakarta.

Sri Setiyati. 2014. Jurnal Pendidikan Teknologi dan Kejuruan: Pengaruh kepemimpinan kepala sekolah, motivasi kerja, dan budaya sekolah terhadap kinerja guru. Vol. 22, No. 2. Fakultas Teknik Universitas Negeri Yogyakarta.

Subarkah. 2013. Kompetensi kewirausahaan kepala sekolah SMK Muhammadiyah 1 Klaten utara pada tahun 2013. Skripsi. UNY. 
Pengaruh Kepemimpinan... (Faya/ hal. 28-37)

Sugiyono. 2019. Statistika untuk penelitian.

Bandung: Alfabeta.

Suhartatik. 2012. Implementasi kepemimpinan dan kewirausahaan kepala smk yadika bangil dalam meningkatkan produktivitas sekolah. Tugas Akhir. Jurusan Ilmu Pengetahuan Sosial. Fakultas Tarbiyah.UIN Malang.

Sumardjo, S., Pratama, G. N. I. P., \& Vemantyasto, T. N. (2020). Efektivitas Modul Estimasi Biaya Konstruksi Jalan pada Mata Pelajaran Estimasi Biaya Konstruksi Di SMK N 1 Purworejo. Jurnal Pendidikan Teknik Sipil,2(2), 104116.

Syaifuddin Azwar. 2011. Penyusunan skala psikologi. Yogyakarta: Pustaka Pelajar Offset.

Titania, T., \& Widodo, S. (2020). Pengembangan Media Pembelajaran Video Animasi untuk Mata Pelajaran Mekanika Teknik Kelas X Desain Pemodelan dan Informasi Bangunan di SMK N 2 Yogyakarta. Jurnal Pendidikan Teknik Sipil, 2(2), 89-94. 